\title{
TG-DTG-DSC, FTIR, DRIFT, and Py-GC-MS Studies of Thermal Decomposition for Poly(sodium acrylate)/Dextrin (PAANa/D) - New Binder BioCo3
}

\author{
Beata Grabowska, ${ }^{\mathrm{a}, *}$, Karolina Kaczmarska ${ }^{\mathrm{a}}$, Artur Bobrowski ${ }^{\mathrm{a}}$, Sylwia Żymankowska-Kumon ${ }^{\mathrm{a}}$, \\ Żaneta Kurleto-Kozioła
}

a AGH University of Science and Technology, Faculty of Foundry Engineering, Reymonta 23, 30-059 Krakow, Poland
*e-mail: beata.grabowska@agh.edu.pl

Received:23 December 2016/Accepted: 14 February 2017/ Published online: 17 March 2017

This article is published with open access at AGH University of Science and Technology Press

\begin{abstract}
TG-DTG-DSC, FTIR, DRIFT, and Py-GC-MS studies have been conducted to determine the effect of the thermal decomposition conditions and structure of foundry binder BioCo3 in the form of a composition poly(sodium acrylate)/dextrin (PAANa/D) on the progress of degradation in terms of processes occurring in foundry sands in contact with liquid metal. TG-DTG-DSC curves of the composition allowed us to determine the temperature range in which they do not undergo degradation, by which they do not lose their binding properties. With temperature increasing, physical and chemical changes occur that are related to the evaporation of solvent water $\left(20-110^{\circ} \mathrm{C}\right)$, followed by the release of constitution water, and finally intermolecular dehydration $\left(110-230^{\circ} \mathrm{C}\right)$. In this temperature range, processes that are mainly reversible take place. Within a temperature range of $450-826^{\circ} \mathrm{C}$, polymer chains are decomposed, including the decomposition of side chains. Within a temperature range of $399-663^{\circ} \mathrm{C}$, polymer composition decomposition can be observed (FTIR, DRIFT), and gas products are generated from this destruction (Py-GC-MS).
\end{abstract}

\section{Keywords:}

polymer binders, foundry sands, thermal analysis, TG-DTG-DSC, FTIR, Py-GC-MS, thermal degradation

\section{INTRODUCTION}

One of the most important challenges in casting processes engineering is skilfully planning the composition of molding sand, in which the binding material (binder) is the key component. The binder serves an importantrole in foundry technology; it not only has the ability to bind the sand grains and provide a specified mechanical strength to loose sand, but it also influences decides the technology influence with this binder on the environment [1]. The binder may be crosslinked in the molding sand by physical or chemical agents so that its bonding strength in the binder-sand system would be sufficient to maintain the desired shape of the molding sand (form) while pouring it with liquid metal; as a result, it could be possible to receive a cast without any defects $[2,3]$. Chemical cross-linking agents supplement the mixture of molding sand, but their presence often intensifies the negative impact of technology on the environment $[4,5]$. For this reason, using new binders based on synthetic and natural polymersin the technology of foundry clearlybrings alot of benefits. However, there is a question as to how it behaves under the influence of sudden increases in temperature during the production of castings. Particularly important are the issues associated with determining the process of degradation and destruction [6, 7]. In addition, another important issue is the determination of the influence of gas products created during thermal destruction on the quality of the final cast as well as on the environment $[8,9]$.

After thermal analysis, polymer binder BioCo3 belongs to a new group of binding materials that are ternary polymer compositions containing water and a synthetic polymer that comes from an acrylic polymers group (poly (acrylic acid) - PAA or poly(sodium acrylate) - PAANa) and modified polysaccharide (sodium salt carboxymethyl - CMS, dextrin - D) $[10,11]$. The polymer compositions that are being considered are complex systems, and analysis of thermal degradation requires extensive knowledge within the scope of the literature related to the thermal properties of initial polymer components [12-16].

On the basis ofliterature data,itcan be concluded that the thermal degradation of acrylic polymers often proceeds specific cross-linking reactions, which is revealed in the occurrence of endothermic effects within a temperature range of $120-180^{\circ} \mathrm{C}$ on the DSC curves. These effects are related to dehydration and the formation of short 
polymer chains $[12,13]$. In the case of polysaccharides within a temperature range of $300-450^{\circ} \mathrm{C}$, weak bonds of $\mathrm{C}-\mathrm{O}-\mathrm{C}$ and $\mathrm{C}-\mathrm{C}$ in the glycoside ring can fall apart. Then, as the temperature rises, it starts a reaction of detaching the side groups that, in conjunction with the breaking of $\mathrm{C}-\mathrm{O}$ bonds, leads to the depolymerization of the chain. The final effect (at approximately $500^{\circ} \mathrm{C}$ ) comes with the total destruction of the dehydrated polymer and the forming of volatile products and charred material [14-16].

\section{EXPERIMENTAL}

\subsection{Material}

Thermal analysis involving the BioCo3 binder as polymer composition of poly (acrylic acid) and dextrin (PAANa/D, Fig. 1) cross-linked with microwave radiation.

Characterization and cross-linking conditions of PAANa/D are provided in Table 1.

a)
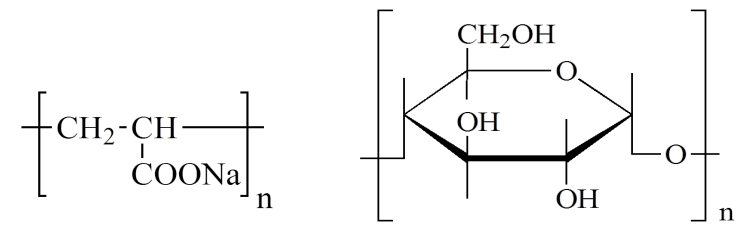

Fig. 1. Structural formula of a) poly(sodium acrylate) and b) dextrin

\section{Table 1}

Characteristics of compositions and their cross-linking parameters

\begin{tabular}{cc}
\hline BioCo3 - composition PAANa/D & Hardening conditions \\
\hline & Microwave device: Sam- \\
40\% aqueous solution & sung MG23H3125NK \\
of poly(sodium acrylate) & Microwave power of $800 \mathrm{~W}$ \\
\cline { 2 - 2 } (PAANa, BASF) and dextrin & Frequency of $2.45 \mathrm{GHz}$ \\
\cline { 2 - 2 } (D, modified potato starch, & Microwave action time: $60 \mathrm{~s}$ \\
Fluka), at a weight & Temperature inside \\
ratio of 9:8, pH 8.5. & the device: $100^{\circ} \mathrm{C}$ \\
\hline
\end{tabular}

Polymer composition PAANa/D after cross-linking in the microwaves field was used for the thermo-analytical research (TG-DTG-DSC, Py-GC-MS). In addition, structural tests (FTIR) were conducted on a sample heated to a temperature range of $20-826^{\circ} \mathrm{C}$. The heating of PAANa/D was carried out in a SNOL 7.2/1300 oven with a velocity of heating of about $10^{\circ} \mathrm{C} / \mathrm{min}$. The total time of the heating process of the sample in the oven was $80 \mathrm{~min}$.

\subsection{Examinations}

\section{TG-DTG-DSC}

The thermal examinations were carried out using a NETZSCH STA 449 F3 Jupiter $®$ thermal analyzer, which supports simultaneous TG and DSC measurements (thus providing two independent signals recorded in the same measurement conditions; namely, at the same temperature increase rate $\left(10^{\circ} \mathrm{C} / \mathrm{min}\right)$, atmosphere and gas flow rate $(40 \mathrm{ml} / \mathrm{min})$. Measurements for the sample were taken in both oxidizing (air) and oxygen-free (argon) atmospheres. The sample submitted to the TG-DSC thermal analysis weighed approximately $15 \mathrm{mg}$. Platinum crucibles were used, as they allowed for measurements up to $1000^{\circ} \mathrm{C}$.

\section{FTIR and DRIFT}

The research was conducted by using the transmission technique (with KBr pellets) and DRIFT with the use of a Digilab Excalibur FTS $3000 \mathrm{Mx}$ spectrometer. A potassium bromide mixture (about $200 \mathrm{mg}$ ) with an adequate amount of the researched sample was pressed in a hydraulic press in a special matrix. The spectrum was recorded by the Resolution Pro program, within an infrared radiation range of $4000-400 \mathrm{~cm}^{-1}$ with a power of resolution of $4 \mathrm{~cm}^{-1}$. The preparation of samples involved heating continuously at a set temperature in a Snol Lab 7.2/1300 oven with a rate of heating of about $10^{\circ} \mathrm{C} / \mathrm{min}$. The time for achieving the highest temperature point $\left(826^{\circ} \mathrm{C}\right)$ was $80 \mathrm{~min}$. The study of FTIR-DRS with the DRIFT method was made by using a watercooled high-temperature attachment coupled with a temperature controller, with the possibility of heating the sample to a temperature of $500^{\circ} \mathrm{C}$. Registration of the spectra was carried out within a range of 4000-600 $\mathrm{cm}^{-1}$, with the ability to dash $8 \mathrm{~cm}^{-1}$. The time of receiving the set temperature was as follows (respectively):

- $20-148^{\circ} \mathrm{C}(45 \mathrm{~s})$,

- $148-298^{\circ} \mathrm{C}(105 \mathrm{~s})$,

- $298-450^{\circ} \mathrm{C}(240 \mathrm{~s})$,

- $450-495^{\circ} \mathrm{C}(900 \mathrm{~s})$.

The total measurement time was $21 \mathrm{~min}$ and $30 \mathrm{~s}$.

\section{Py-GC-MS}

The pyrolysis gas chromatography (Py-GC/MS) method is based on transforming a solid sample (2-3 $\mathrm{mg}$ ) into gas by heating in an atmosphere of inert gas (helium) in a pyrolyzer "Py" Pyroprobe 5000 (CDS Analytical Inc.), which is accompanied by thermal decomposition. It has a platinum ribbon, which enables the heating of a sample to any temperature within a range of $240-1300^{\circ} \mathrm{C}$. The obtained mixture of compounds (pyrolysate) is separated on a chromatographic column in a chromatograph "GC" (Focus GC, Thermo Scientific). A temperature program was applied: an initial temperature of $40^{\circ} \mathrm{C}$ was held for $3 \mathrm{~min}$; ramped $3^{\circ} \mathrm{C} / \mathrm{min}$ up to $100^{\circ} \mathrm{C}$ and held for $3 \mathrm{~min}$, and then $250^{\circ} \mathrm{C}$ with a heating rate of $20^{\circ} \mathrm{C} / \mathrm{min}$ was maintained for $3 \mathrm{~min}$ (helium carrier gas at $1 \mathrm{ml} / \mathrm{min}$, sample split ratio 1:30). The separated compounds are analyzed in a mass spectrometer "MS" (ISQ Thermo Scientific) in the full range mass number/ 
charge number $(\mathrm{m} / \mathrm{z})$. Electron ionisation $(70 \mathrm{eV})$ at a temperature of $250^{\circ} \mathrm{C}$ was applied.

\section{RESULTS AND DISCUSSION}

\section{TG-DTG-DSC}

In an oxidizing atmosphere (air), decomposition of the cross-linked PAANa/D polymer composition occurs with five weight losses (Fig. 2).

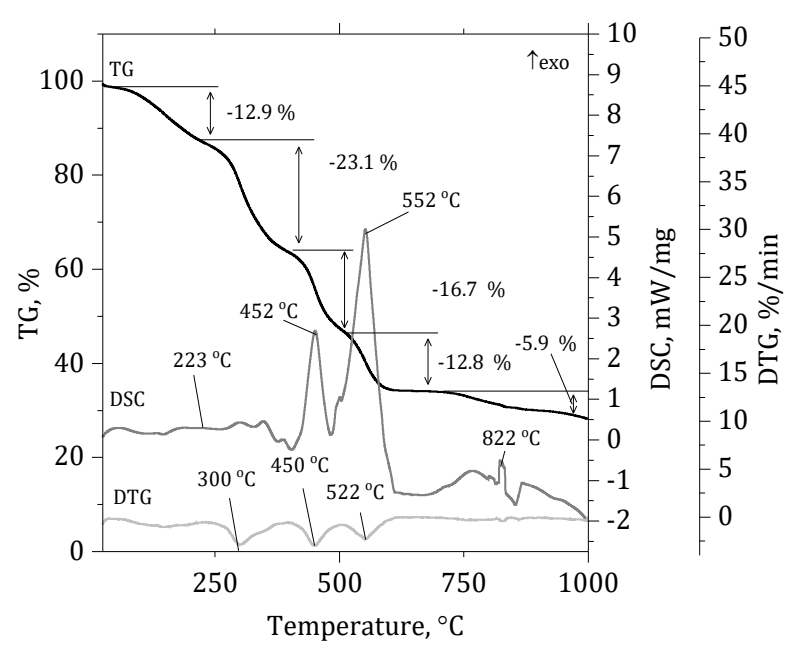

Fig. 2.TG-DTG-DSC curves of composition PAANa/D in oxidizing atmosphere

Within a temperature range of $20-110^{\circ} \mathrm{C}$, the remains of the solvent water evaporate, followed by the constitution water. Next, within a temperature range of $110-230^{\circ} \mathrm{C}$, the intermolecular dehydration reaction takes place. In this temperature range, mainly reversible processes occur: physical transformations and reversible reactions. On the basis of TG curves, it can be stated that the thermal degradation process starts at a temperature of approx. $230^{\circ} \mathrm{C}$. Next, polymer chains decompose, including the decomposition of side chains and glycosidic bonds. Further on, progressive decomposition takes place with the intensive generation of gas products of destruction, including combustion reactions in an oxygen atmosphere. At the DSC curve at temperature of $452^{\circ}, 552^{\circ}$, and $822^{\circ} \mathrm{C}$, there are three exothermic effects visible (which may be the result of the PAANa/D combustion process). Moreover, three peaks can be noticed at the DTG curve: $300^{\circ} \mathrm{C}, 450^{\circ} \mathrm{C}$, and $522^{\circ} \mathrm{C}$. A sample of the composition PAANa/D almost completely decomposes to a temperature of $1000^{\circ} \mathrm{C}$ (residual sample mass - $28.6 \%$ ).

In the oxygen-free atmosphere (argon), the PAANa/D decomposition process is different (Fig. 3). At the TG curve of the composition, four weight losses $(\Delta \mathrm{m})$ can be observed, while three endothermic effects are visible at the DSC curve. At the DTG curve, one can notice three peaks: $298^{\circ} \mathrm{C}, 450^{\circ} \mathrm{C}$ and $826^{\circ} \mathrm{C}$. The residual part of the composition sample mass (approx. $11.7 \%$ ) probably contains carbonized carbon and low-molecular-weight compounds with sodium atoms, which means that BioCo3 did not decompose at a temperature of $1000^{\circ} \mathrm{C}$.

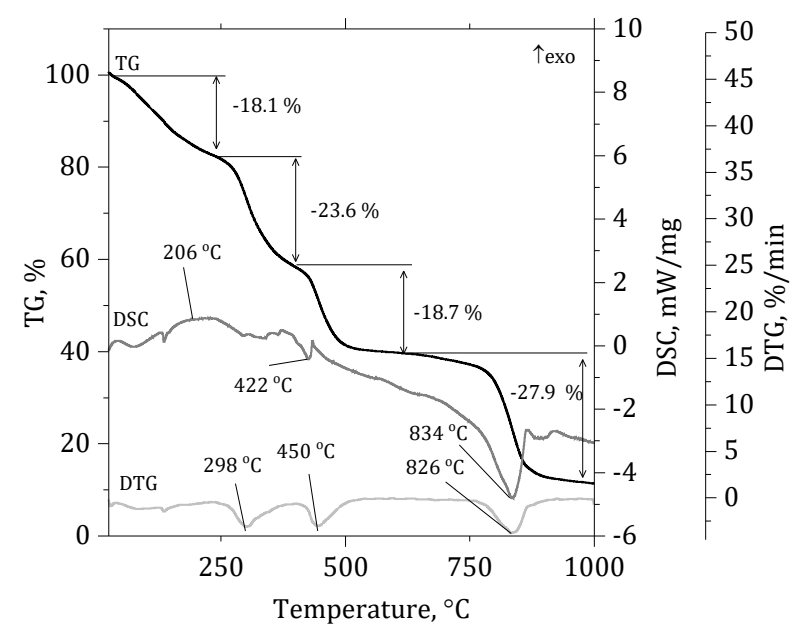

Fig. 3. TG-DTG-DSC curves of PAANa/D composition in argon atmosphere

\section{FTIR and DRIFT}

Figures 4 and 5 show the IR spectra for the PAANa/D recorded at a temperature range of $20-826^{\circ} \mathrm{C}$. The PAANa/D composition was heated in the oven, and its sample used for the FTIR tests was collected at specific temperatures. Spectroscopic studies in infrared were carried out with the FTIR method (Fig. 4) and DRIFT method (Fig. 5). The temperature values in which the IR spectrum was recorded were $298^{\circ} \mathrm{C}, 450^{\circ} \mathrm{C}, 552^{\circ} \mathrm{C}$, $826^{\circ} \mathrm{C}$. The temperature was determined on the basis of observed mass losses and the thermal effects on the course of TG-DTG-DSC curves. The PAANa/D sample was heated in the oven to the set temperature; then, the next spectrum was recorded.

On the IR spectra obtained by the FTIR and DRIFT methods (Figs. 4 and 5, respectively), a wide band within a range of wavenumbers $3800-3000 \mathrm{~cm}^{-1}$ corresponds to the vibration of a free group $(\mathrm{OH})$ from water and from the existence of hydrogen bonds. At a temperature of $298^{\circ} \mathrm{C}$, a lower intensity of this band can be observed; this is connected with the solvent and evaporation of constitutional water. In addition, a change in band shape at around $1570 \mathrm{~cm}^{-1}$ and the forming of a new band $\left(1735 \mathrm{~cm}^{-1}\right)$ shows a progressive reaction caused by the higher temperature (Fig. 4).

The band corresponding to the wavenumbers at around $1735 \mathrm{~cm}^{-1}$ (FTIR - Fig. 4) and $1740 \mathrm{~cm}^{-1}$ (DRIFT - Fig. 5) indicates the presence of carbonyl groups $(C=0)$, which corresponds to the following chemical changes associated with the formation of new compounds in the thermal degradation process. This temperature range also creates a reaction of dehydration with the formation of the anhydride groups - for this reason, some changes in the spectrum be can observed. Two bands at around $1456 \mathrm{~cm}^{-1}$ and $1408 \mathrm{~cm}^{-1}$ are assigned to the symmetric stretching vibration of $\mathrm{C}-\mathrm{H}$ bonds that occurs in the structure of PAANa/D (Fig. 4). At a temperature of $450^{\circ} \mathrm{C}$, a new band is formed in the same range with wavenumber $1430 \mathrm{~cm}^{-1}$, and then it moves towards higher numbers $\left(1437 \mathrm{~cm}^{-1}\right)$. 


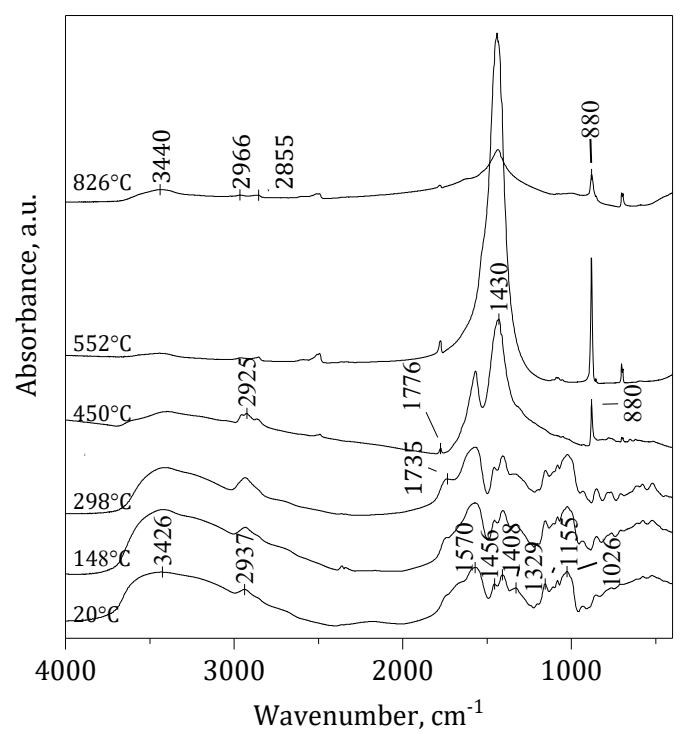

Fig. 4. IR spectra of PAANa/D obtained by FTIR method

These changes indicate chemical changes within the carbon skeleton ( $-\mathrm{C}-\mathrm{C}-\mathrm{C}-)$ related to the breaking of hydrocarbon chains. Also, the change of the position of band $2937 \mathrm{~cm}^{-1} \rightarrow 2925 \mathrm{~cm}^{-1}$ indicates changes in the hydrocarbon chain. The band with its peak near wavenumber $1329 \mathrm{~cm}^{-1}$ is assigned to the $\mathrm{O}-\mathrm{H}$ group stretching vibration (IR spectrum recorded at a temperature of $20^{\circ} \mathrm{C}$ ). At a temperature of $450^{\circ} \mathrm{C}$, this band is lost; this is associated with degradation of the hydroxyl groups. In addition, the appearance of two new bands is noticed on the IR spectrum obtained by the DRIFT method for the PAANa/D sample heated at $450^{\circ} \mathrm{C}$ (Fig. 5); one at $2463 \mathrm{~cm}^{-1}$, and an intensive band at $2360 \mathrm{~cm}^{-1}$. These bands can also be attributed to the new hydrocarbon systems.

Additionally, three new bands appear at $826^{\circ} \mathrm{C}$ (IR spectrum obtained by the FTIR method): $3400 \mathrm{~cm}^{-1}$, $2966 \mathrm{~cm}^{-1}$, and $2855 \mathrm{~cm}^{-1}$ are associated with the aromatic $\mathrm{C}-\mathrm{H}$ out-of-plane bending vibrations. The occurrence of these bands indicates the progressive formation of aromatic compounds. In addition, the band at $880 \mathrm{~cm}^{-1}$ that were observed on the spectra also shows the formation of some new aromatic compounds.

\section{Py-GC-MS}

In order to obtain further information regarding the thermal decomposition of PAANa/D in the context of the impact on the environment of molding sand bonded by the BioCo3 binder, a coupled analytical technique was used in these studies: pyrolytic gas chromatography coupled with mass spectroscopy (Py-GC-MS). Application of the Py-GC-MS method made it possible to submit gaseous products formed in the process of PAANa/D destruction for qualitative analysis. The temperature values in which decomposition has been carried out (as in the case of the IR measurements) were selected on the basis of thermal analysis TG-DTG-DSC curves. Figure 6 shows the chromatograms recorded for the PAANa/D sample submitted for pyrolysis at $298^{\circ} \mathrm{C}, 450^{\circ} \mathrm{C}, 552^{\circ} \mathrm{C}$ and $826^{\circ} \mathrm{C}$.

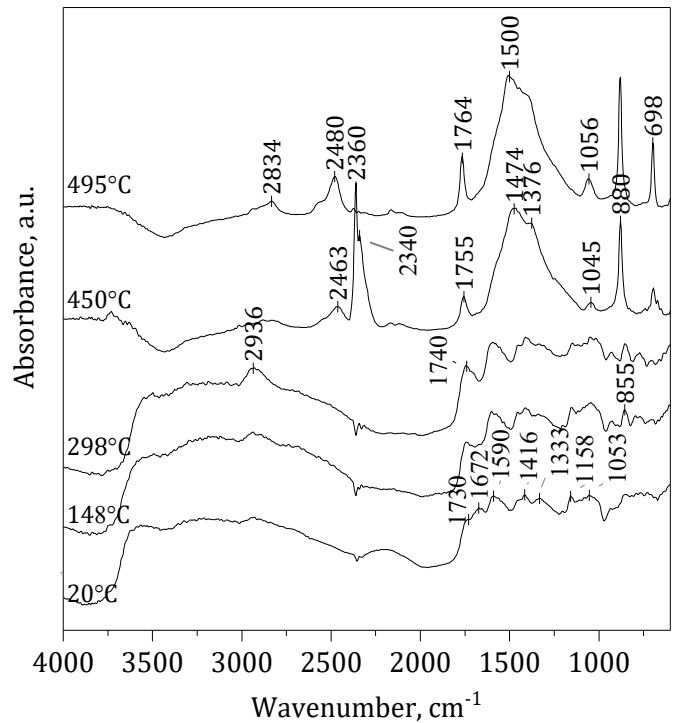

Fig. 5. IR spectra of PAANa/D obtained by DRIFT method

a)

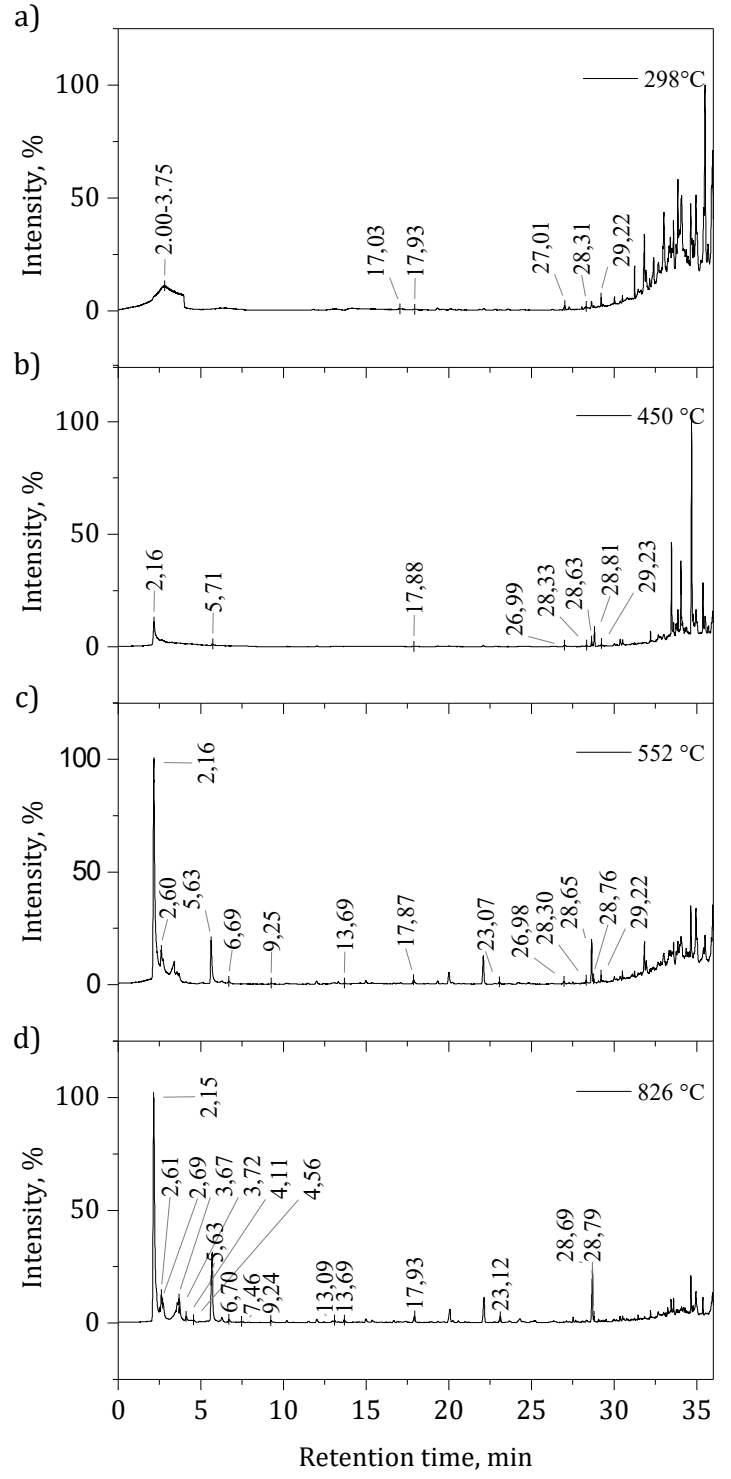

Fig. 6. Chromatograms obtained for PAANa/D samples at the following temperature: a) $298^{\circ} \mathrm{C}$; b) $450^{\circ} \mathrm{C}$; c) $552^{\circ} \mathrm{C}$; d) $826^{\circ} \mathrm{C}$ 
Table 2 depicts the results of the qualitative analysis. Qualitative analysis was carried out with the use of the 2.2 Xcalibur (NIST MS Search 2.0) program.

Table 2

Results of Py-GC-MS investigations

\begin{tabular}{|c|c|c|c|c|c|}
\hline \multirow{2}{*}{ Compounds } & \multirow{2}{*}{$\mathbf{M}_{\mathrm{w}}{ }^{*}$} & \multicolumn{4}{|c|}{ Retention time RT, min } \\
\hline & & $298^{\circ} \mathrm{C}$ & $450^{\circ} \mathrm{C}$ & $552^{\circ} \mathrm{C}$ & $826^{\circ} \mathrm{C}$ \\
\hline Carbon dioxide & 44 & $2-3,75$ & 2,16 & 2,16 & 2,15 \\
\hline Isopropyl alcohol & 60 & - & - & - & 2,61 \\
\hline Ethanoic acid & 60 & - & - & - & 3,67 \\
\hline Glycolaldehyde & 60 & - & - & - & 3,72 \\
\hline $\begin{array}{l}\text { Hydroxymethyl- } \\
\text { cyclopropane }\end{array}$ & 72 & - & 28,63 & 28,65 & 28,69 \\
\hline $\begin{array}{l}\text { Methoxyace- } \\
\text { taldehyde }\end{array}$ & 74 & - & - & 2,60 & 4,11 \\
\hline Acetol & 74 & - & 5,71 & 5,63 & 5,63 \\
\hline Benzene & 78 & - & - & - & 4,56 \\
\hline Cyclopentenone & 82 & - & - & 13,69 & 13,69 \\
\hline 2-butanone & 88 & - & - & 6,69 & 6,70 \\
\hline $\begin{array}{l}\text { 1-hydroxy- } \\
\text {-2-butanone }\end{array}$ & 88 & - & - & 9,25 & 9,24 \\
\hline 2-Propanone & 88 & - & - & - & 2,69 \\
\hline Toluene & 92 & - & - & - & 7,46 \\
\hline $\begin{array}{l}\text { 2-Hydroxycyclo- } \\
\text { pent-2-en-1-one }\end{array}$ & 98 & 17,93 & 17,88 & 17,87 & 17,93 \\
\hline $\begin{array}{l}\text { 2-Cyclopen- } \\
\text { ten-1-one }\end{array}$ & 112 & - & - & 23,07 & 23,12 \\
\hline Hexanoic acid & 116 & 17,03 & - & - & - \\
\hline Levoglucosenone & 126 & - & 28,81 & 28,76 & 28,79 \\
\hline Octanoic acid & 144 & 27,01 & 26,99 & 26,98 & - \\
\hline Nonanoic acid & 158 & 29,22 & 29,23 & 29,22 & - \\
\hline Dodecanoic acid & 216 & 28,31 & 28,33 & 28,30 & - \\
\hline
\end{tabular}

${ }^{*} \mathrm{M}_{\mathrm{W}}$ - molecular weight, $\mathrm{u}$

At $298^{\circ} \mathrm{C}$, carbon dioxide, 2-hydroxycyclopent-2-en-1-one, and carboxylic acids were found. At $450^{\circ} \mathrm{C}$, hydroxymethylcyclopropane, acetol, and levoglucosenone were also formed. At $552^{\circ} \mathrm{C}$ (with the aforementioned, methoxyacetaldehyde, cyclopentenone, and 2-butanone), 1-hydroxy-2-butanone and 2-cyclopenten-1-one are also created. Based on the compiled results, it can be concluded that the compounds from the aromatic hydrocarbon group are only generated at $826^{\circ} \mathrm{C}$. At this temperature, some marks of of benzene, toluene, ethyl benzene, xylene, and naphthalene decomposition were found in the products. There was no sign of the existence of carboxylic acids.

\section{CONCLUSIONS}

On the basis of the obtained results of TG-DTG-DSC, FTIR, DRIFT, and Py-GC-MS, it can be stated that the course of decomposition is a complex process, which is a result of the structure as well as the physical and chemical properties of the analyzed BioCo3 bidres in form composition of PAANa/D. With a temperature increase, physical and chemical changes occur in the analyzed sample of the polymer PAANa/D composition.

Within the temperature range of $20-110^{\circ} \mathrm{C}$, the evaporation of physically bound water occurs, followed by constitution water; and above a temperature of $110^{\circ} \mathrm{C}$, an intermolecular dehydration reaction takes place with the formation of intermolecular anhydride bonds, which is characteristic of the thermal decomposition of poly(acrylic acid). Above a temperature of $450^{\circ} \mathrm{C}$, intensive cracking of the chemical bonds occurs, which results in the breaking of most bonds. The process becomes massive, which has an effect of releasing volatile low-molecular-weight inorganic $\left(\mathrm{CO}_{2}\right)$ and organic compounds, and finally leads to the complete degradation of BioCo3.

Knowledge about the thermal stability of BioCo3 obtained from the studies of the TG-DTG-DSC, FTIR, and Py-GC-MS thermal analysis methods has allowed us to identify the process of PAANa/D degradation in the context of its use as a binder in molding sand. This allows us to better understand the phenomena that constantly occurr in molding sand bonded by polymer binder BioCo 3 during the process of pouring the mold with liquid metal.

\section{REFERENCES}

[1] Lewandowski J. L. (1995). Tworzywa na formy odlewnicze. Kraków: Akapit.

[2] Zhou X., Yang J., Su D. \& Qu G. (2009). The high-temperature resistant mechanism of $\alpha$-starch composite binder for foundry. Journal of Materials Processing Technology, 209(14), 5394-5398. doi:10.1016/j.jmatprotec.2009.04.010

[3] Fayomi O.S.I., Abdulwahab M. \& Popoola A.P.I. (2014). Potentials of Elaeis guineensis and Pinus sylvestris as binders on foundry core strength. Journal of Scientific and Industrial Research, 73(3), 173-176. doi:10.5897/IJPS12.347

[4] Miguel R.E., Ippolito J.A., Leytem A.B., Porta A.A., Banda Noriega R.B. \& Dungan R.S. (2012). Analysis of total metals in waste molding and core sands from ferrous and non-ferrous foundries. Journal of Environmental Management, 110, 77-81. doi:10.1016/j.jenvman.2012.05.025

[5] Dungan R.S., Kukier U. \& Lee B. (2006). Blending foundry sands with soil: Effect on dehydrogenase activity. Science of the Total Environment, 357(1-3), 221-230. doi:10.1016/j. scitotenv.2005.04.032

[6] Fox J.T., Cannon F.S., Brown N.R., Huang H. \& Furness J.C. (2012). Comparison of a new, green foundry binder with conventional foundry binders. International Journal of Adhesion and Adhesives, 34, 38-45. doi:10.1016/j. ijadhadh.2011.11.011

[7] Grabowska B., Szucki M., Suchy J.S., Eichholz S. \& Hodor K. (2013). Thermal degradation behavior of cellulose-based material for gating systems in iron casting production. Polimery, 58(1), 39-44.

[8] Kubecki M., Holtzer M. \& Żymankowska S. (2013). Investigations of the Temperature Influence on Formation of Compounds from the BTEX Group During the Thermal Decomposition of Furan Resin. Archives of Foundry Engineering, 13(2), 85-90.

[9] Bobrowski A., Holtzer M., Żymankowska-Kumon S. \& Dańko R. (2015). Harmfulness assessment of moulding sands with a geopolymer binder and a new hardener, in an aspect of the emission of substances from the BTEX Group. Archives of Metallurgy and Materials, 60(1), 341-344. doi:10.1515/amm-2015-0056

[10] Grabowska B., Holtzer M., Dańko, R. Górny M., Bobrowski A. \& Olejnik E. (2013). New BioCo binders containing biopolymers for foundry industry. Metalurgija, 52(1), 47-50. 
[11] Grabowska B., Sitarz M., Olejnik E., Kaczmarska K. \& Tyliszczak B. (2015). FT-IR and FT-Raman studies of cross-linking processes with $\mathrm{Ca}^{2+}$ ions, glutaraldehyde and microwave radiation for polymer composition of poly(acrylic acid)/sodium salt of carboxymethyl starch - In moulding sands, Part II. Spectrochimica Acta - Part A: Molecular and Biomolecular Spectroscopy, 151, 27-33. doi:10.1016/j.saa.2015.06.084

[12] Pielichowski J. \& Pielichowski K. (1995). Application of thermal analysis for the investigation of polymer degradation processes. Journal of Thermal Analysis, 43, 505-508.

[13] Lattimer R.P. (2003). Pyrolysis mass spectrometry of acrylic acid polymers. Journal of Analytical and Applied Pyrolysis, 69(5), 3-14. doi:10.1016/S0165-2370(03)00080-9

[14] Kader M.A. \& Bhowmick A.K. (2003). Thermal ageing, degradation and swelling of acrylate rubber, fluororubber and their blends containing polyfunctional acrylates. Polymer Degradation and Stability, 79(2), 283-295. doi:10.1016/ S0141-3910(02)00292-6
[15] Lluch A.V., Felipe A.M., Greus A.R., Cadenato A., Ramis X., Salla J.M. \& Morancho J.M. (2005). Thermal analysis characterization of the degradation of biodegradable starch blends in soil. Journal of Applied Polymer Science, 96(2), 358-371. doi:10.1002/app.21428

[16] Lawal O.S., Lechner M.D. \& Kulicke W.M. (2008). The synthesis conditions, characterizations and thermal degradation studies of an etherified starch from an unconventional source. Polymer Degradation and Stability, 93, 1520-1528. doi:10.1016/j.polymdegradstab.2008.05.010 